\title{
Society for Social Medicine 53rd Annual Scientific Meeting, 9-11 September 2009, the University of Newcastle
}

\begin{tabular}{|c|c|c|c|}
\hline \multicolumn{2}{|c|}{ Wednesday 9 September } & \multirow{2}{*}{$\begin{array}{l}13.00-14.00 \\
14.00-16.30\end{array}$} & \multirow{2}{*}{$\begin{array}{l}\text { Posters and exhibits (King's Hall) } \\
4 \text { workshops in parallel (Bedson Teaching Centre) }\end{array}$} \\
\hline $10.00-18.00$ & Registration (King's Hall) & & \\
\hline \multirow[t]{2}{*}{$12.15-13.45$} & Lunch available to purchase (King's Walk & $13.15-17.30$ & Trips (transport provided from King's Walk) \\
\hline & $\begin{array}{l}\text { Bistro) } \\
\text { Invited reception for invited speakers, new }\end{array}$ & $18.45-19.30$ & $\begin{array}{l}\text { Coaches to dinner (from Castle Leazes and } \\
\text { main hotels) }\end{array}$ \\
\hline \multirow{2}{*}{$12.45-13.45$} & members, students, SSM Committee and & $19.30-00.00$ & Conference dinner (Beamish Hall) \\
\hline & $\begin{array}{l}\text { Local Organising Committee (Bamburgh Room, } \\
\text { King's Walk) }\end{array}$ & $22.00-00.00$ & $\begin{array}{l}\text { Coaches to accommodation (Castle Leazes } \\
\text { and main hotels) }\end{array}$ \\
\hline $12.45-13.45$ & Posters and exhibits & & \\
\hline \multirow[t]{2}{*}{$14.00-14.15$} & Welcome (Curtis Auditorium, Herschel & \multicolumn{2}{|c|}{ Friday 11 September } \\
\hline & Buildir & $08.30-14.30$ & Registration (King's Hall) \\
\hline \multirow[t]{4}{*}{$14.15-15.00$} & Cochrane Lecture (Curtis Auditorium) & $09.00-09.20$ & Parallel Session $\mathrm{C}-6$ papers in parallel \\
\hline & Good intentions and received wisdom are not & $09.25-09.45$ & Parallel Session $\mathrm{C}-6$ papers in parallel \\
\hline & good enough & $09.50-10.10$ & Parallel Session $\mathrm{C} \_6$ papers in parallel \\
\hline & S Macl & $10.15-10.35$ & Parallel Session C_-6 papers in parallel \\
\hline $15.00-15.30$ & Refreshments and poster viewing (King's Hall) & $10.35-11.05$ & Refreshments and poster viewing (King's Hall) \\
\hline $15.30-15.50$ & Parallel Session $A-6$ papers in parallel & $11.05-11.25$ & Parallel Session D—6 papers in parallel \\
\hline $15.55-16.15$ & Parallel Session $A-6$ papers in parallel & $11.30-11.50$ & Parallel Session D_6 papers in parallel \\
\hline $16.20-16.40$ & Parallel Session $A-6$ papers in parallel & $11.55-12.15$ & Parallel Session $\mathrm{D}-6$ papers in parallel \\
\hline $16.45-17.05$ & Parallel Session $A-6$ papers in parallel & $12.20-12.40$ & Plenary paper 1 (Curtis Auditorium) \\
\hline $17.15-18.15$ & AGM (Bedson 1.46) & & Are poor mothers and their infants healthier in \\
\hline 19.15-20.45 & $\begin{array}{l}\text { Conference reception (Riverside Suite, BALTIC } \\
\text { Centre for Contemporary Arts) }\end{array}$ & $12.40-13.00$ & $\begin{array}{l}\text { richer areas? The protective effect of area } \\
\text { socio-economic density C Albor et al } \\
\text { Plenary paper } 2 \text { (Curtis Auditorium) }\end{array}$ \\
\hline \multicolumn{2}{|c|}{ Thursday 10 September } & & Second hand smoke exposure assessed using \\
\hline $08.30-18.00$ & Registration (King's Hall) & & serum cotinine: associations with MI, stroke, \\
\hline $09.00-09.20$ & Parallel Session B-6 papers in parallel & & d cordionocoular rick factore in adult mon \\
\hline $09.25-09.45$ & Parallel Session B-6 papers in parallel & & \\
\hline $09.50-10.10$ & Parallel Session B-6 papers in parallel & & 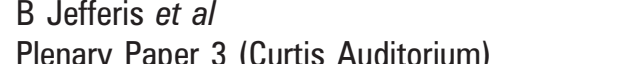 \\
\hline $10.15-10.35$ & Parallel Session B-6 papers in parallel & & Cost effectiveness of alternative screening \\
\hline $10.35-12.00$ & Refreshments and poster viewing (King's Hall) & & strategies for identifying people at high risk of \\
\hline \multirow[t]{2}{*}{$11.00-12.00$} & Poster session- $10 \times 6$ parallel poster & & cardiovascular disease $\mathrm{K}$ Lawson et al \\
\hline & Presentations & $13.20-13.30$ & Awards and closing remarks (Curtis \\
\hline \multirow[t]{3}{*}{$12.10-13.00$} & Pemberton Lecture (Curtis Auditorium) & & Auditorium) \\
\hline & The causes and prevention of breast cancer & $13.30-14.30$ & Lunch, by ticket (King's Walk Bistro) \\
\hline & & $13.30-14.30$ & Posters and exhibits \\
\hline $13.00-14.00$ & Lunch, by ticket (King's Walk Bistro) & 14.30 & Close \\
\hline
\end{tabular}

